\title{
On the Development of Catamaran Hull Form for Fish Processing Vessel to Support Domestic Fishing Activities in Indonesia
}

\section{O razvoju oblika trupa katamarana za brod za preradu ribe kao podršci nacionalnom ribarstvu u Indoneziji}

\author{
Ahmad Fauzan Zakki \\ Diponegoro University \\ Semarang-Indonesia \\ E-mail: ahmadfauzanzakki@lecturer.undip.ac.id
}

\author{
Deddy Chrismianto \\ Diponegoro University \\ Semarang-Indonesia \\ E-mail: deddychrismianto@lecturer.undip.ac.id
}

\author{
Aulia Windyandari \\ Diponegoro University \\ Semarang-Indonesia \\ E-mail: auliawindyandari@lecturer.undip.ac.id
}

\section{Summary}

Several advantages of multihull, such as catamaran, have been extensively discussed in the previous research. Therefore, this research focuses on developing a catamaran hull form for the fish processing vessel hull. The initial stage is determining the principal dimension and exploring the configurations of catamaran hull forms. The existing high-speed craft catamarans have been adopted to determine the parent model main dimensions using a linear regression equation model. Otherwise, the catamarans single demi-hull geometry was developed by converting and modifying the parent model hull form with enlarging the hull displacement to achieve the deadweight capacity and service speed requirements. The demi-hull spacing configuration with $\mathrm{s} / \mathrm{L} 0.17, \mathrm{~s} / \mathrm{L} 0.20, \mathrm{~s} / \mathrm{L} 0.30$, and $\mathrm{s} / \mathrm{L} 0.40$ on the resistance characteristics, intact stability, and sea-keeping behaviour were also explored. Furthermore, the comparisons with the previously proposed monohull were presented. Regarding the hull resistance performance, the analysis indicated that the catamaran hull form had better total resistance characteristics than the monohull on the service speed over 23 knots. In the case of intact stability, the analysis results presented that the catamaran hull form has better intact stability characteristics than the monohull. The dynamic stability of the catamarans also gave better dynamic stability at the heeling angle below $41.57^{\circ}$. Otherwise, the catamarans with $\mathrm{s} / \mathrm{L} 0.17$ and $\mathrm{s} / \mathrm{L} 0.20$ have lower dynamic stability than the monohull at the heeling angle larger than $41.57^{\circ}$ and $58.03^{\circ}$, respectively. In the sea-keeping performance, the catamaran hull has shown an excellent rolling motion required for the offshore environment loading/unloading process. The large demi hull spacing of the catamarans hull can reduce the effect of the wave creating load on the roll motion response at the Beam Sea.

\section{Sažetak}

Nekoliko prednosti višetrupaca, kao što je katamaran, detaljno je obrađeno u ranijim istraživanjima. Zato je ovo istraživanje usmjereno na razvoj oblika trupa katamarana kao trupa broda za preradu ribe. U početnoj fazi utvrđuju se osnovne dimenzije $i$ ispituje konfiguracije oblika trupa katamarana. Postojeći brzi katamarani prilagođeni su kako bi se odredile glavne dimenzije osnovnog modela koristeći se pritom jednadžbom linearne regresije. Pored toga, razrađena je geometrija jednostrukog polu-trupa pretvaranjem i modificiranjem osnovnoga modela oblika trupa na način da se povećala istisnina trupa kako bi se udovoljilo zahtjevima pune nosivosti trupa i brzine broda. Također je ispitana konfiguracija prostora kao polutrupa sa $s / L$ 0,17, s/L 0,20, s/L 0,30 i s/L 0,40 na karakteristike otpora, siguran stabilitet i ponašanje na moru. Dane su usporedbe $s$ ranije predloženim višetrupcem. Što se tiče otpora trupa, analiza je pokazala da je trup katamarana imao ukupno bolje karakteristike otpora nego jednotrupac kod brzine preko 23 čvora. Što se tiče stabiliteta, rezultati analize pokazali su da je stabilitet bolji kod trupa katamarana nego kod jednotrupca. Dinamički stabilitet katamarana također se pokazao boljim u nagibu pod kutom manjim od $41,57^{\circ}$. Katamarani sa $\mathrm{s} / \mathrm{L}$ 0,17 i s/L 0,20 pokazali su lošiji dinamički stabilitet od jednotrupca u nagibu pod kutem većim od $41,57^{\circ} \mathrm{i} 58,03^{\circ}$. Pri ispitivanju ponašanja na moru, trup katamarana pokazao se izvrsnim u uvjetima valjanja, što je potrebno u operacijama ukrcaja/iskrcaja na moru. Veliki razmak polutrupa katamarana može smanjiti utjecaj valova koji stvaraju opterećenje na trup pri valjanju s boka.

DOI 10.17818/NM/2021/3.5

UDK 629.5.022.22:639.2(594)

Preliminary communication / Prethodno priopćenje Paper accepted / Rukopis primljen: 14. 11. 2020.

\section{KEY WORDS \\ Catamaran \\ monohull \\ fish processing vessel \\ domestic fishing}




\section{INTRODUCTION / Uvod}

In Indonesia, fishing activities are dominated by the small-scale fishing industry and artisanal fishery. The fishing fleet technical aspects have many different typologies depending on their population region, size, distance to the fishing ground, fishing gear type, etc. According to the statistical data, it is shown that the total number of fishing boats with a size of less than $10 \mathrm{GT}$ are 508,551 units which are $94 \%$ of the population, [1]. Among the people, about $68.42 \%$ are non-engine boats and small outboard engine boats. Additionally, the catches handling procedures still follow the traditional methods due to the unavailability of cold storage facilities. The absence of cold storage on board can reduce the catching quality, resulting in the low selling price.

Fishing activities have been categorized as one of the most dangerous professions. About 24,000 fatalities were recorded by the International Labour Organization (ILO), [2]. In many countries, it is also included as the highest fatal injury rates compared to the other sectors, such as the United States, Spain, and the United Kingdom, [3-5]. Many kinds of the cause of the accident have been identified, such as incorrect operational procedures, unbalanced weight distribution, sailing in severe sea states, etc. Although capsizing rarely occurs, accidents are usually related to the failure of the static and dynamic boat stability performance. The lack of training for the boat crew was indicated as the primary cause of the stability-related accidents, especially for the small and medium-sized fishing boats, [68]. Therefore, the improvement of fishing fleet capacity and performance is the main government program that must be implemented to improve the catch productivity, efficiency, quality, and safety of fishing operations.

Recently, the multi-hulls application has significantly increased for marine activities such as leisure boats, fishing boats, ferries, and research vessels, [9]. The multihull technology, especially catamaran, has offered several advantages over monohull such as better transverse intact stability, attractive layout, better total resistance, and smaller size main engine [10, 11]. In this regard, the implementation of multihull technology might answer the problems, restrictions, and requirements for fishing activities in Indonesia.

This research focuses on developing a prototype design of a catamaran hull form for fish processing vessels (FPV) to support domestic fishing activities in Indonesia. The preliminary design of a new catamaran hull form starts with identifying the existing catamaran boat to determine the principal dimension. Then the exploration, creation, and calculation of the new design catamaran hull form are conducted. Since this research is related to the previous research that developed a monohull hull form for the FPV, Fig. 1, [12], the comparison of both hull form performances is presented.

This paper layout is as follows: the literature review of catamaran and fishing vessel characteristics is covered in section 2. The preliminary catamaran hull form development for exploring and creating the hull form lines is outlined in section 3. Section 4 presented the calculation of resistance, intact stability, and seakeeping behaviour to assess the developed catamaran hull form performance. Section 5 elaborates the comparison with monohull to identify the advantages of the proposed catamaran hull form. Section 6 presents the conclusion and recommendations and an outlook according to the result of the analysis.

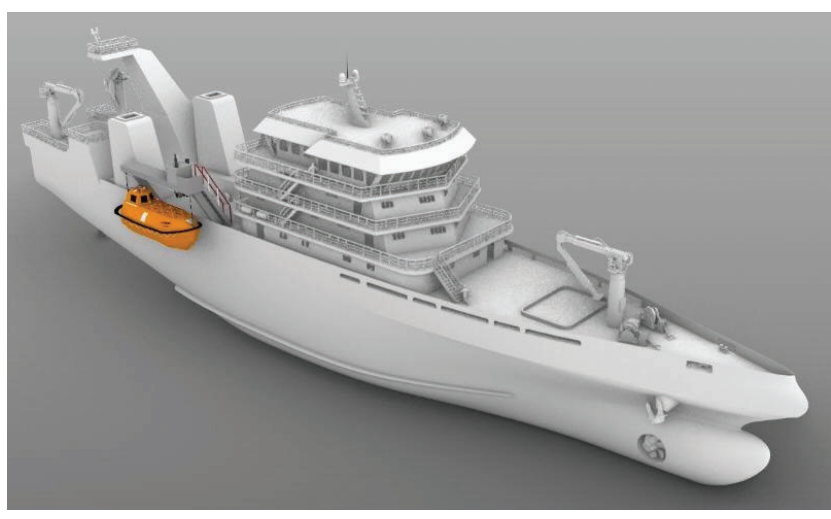

Figure 1 Developed Monohull Hull Form for the Fish Processing Vessel [12]

Slika 1. Oblik trupa kod višetrupca za brod za preradu ribe [12]

\section{LITERATURE REVIEW / Pregled literature}

Many kinds of efforts have been made through a wide variety of hull form design development to improve the performance and increase ships and boat service speed. The vessels design commonly used the submerged body buoyancy force to support the vessel weight to stay floating on the water surface, even though there are other ways such as hydrofoils, air-cushion effect, or a combination of that methods. In lieu of hull form geometry, monohulls and catamarans are generally adopted as the hull design to maintain the motion performance in the developed sea condition.

A monohull has a box-shaped cargo hold and smaller vertical acceleration due to wave excitation compared with the catamaran. However, the catamaran has better transverse intact stability than the monohull. Small Waterplane Area Twin Hull (SWATH) has better sea-keeping conditions in the Head Sea than a catamaran. However, the SWATH has worse performance while exceeding the Froude Number limit, especially when the fins or other control surface devices are not installed, [29]. Therefore, the catamaran is still becoming an excellent alternative hull form geometry to improve transverse stability and increase service speed. Nevertheless, catamaran hydrodynamic characteristics still need to be examined and become an interesting topic to be investigated.

Insel and Molland [10] presented an experimental and theoretical study on the resistance components in the calm water of highspeed displacement and semi-displacement of symmetric demihulls catamarans. The research found that the viscous resistance interference is primarily dependent on demi-hulls length to beam ratio but effectively independent on the speed and hull separation. The study has presented a better understanding of catamaran resistance characteristics, including the influence of hull separation and length to beam ratio. The interference effects of wave and viscous resistance and the practical application are also presented in this study. Molland et al. also conducted a similar analysis to a broader set of catamaran hull forms in the other research, [13].

Other research can also be found, such as Bruzzone et al., [14], study on hull separation length with the boundary element method. Muller-Graf et al., [15], conducted an extensive experimental study on a catamaran systematic series. Hydrodynamics aspects of the fast catamaran were investigated by Welnicki, $[16,17]$. The viscosity influence on the catamaran hydrodynamic behaviour using theoretical approach was conducted by Doctors, [18]. Armstrong, [19], identified the effect of hull separation on the catamaran frictional resistance. Numerical and experimental investigation of hull clearance was presented 
Table 1 The collected existing catamaran vessels

Tablica 1. Podatci o svim postojećim katamaranima

\begin{tabular}{|c|c|c|c|c|c|c|c|}
\hline No & The Name of Ship & DWT & LOA & LBP & B & $\mathrm{T}$ & $\mathrm{D}$ \\
\hline 1 & Volcan De Tano & 700 & 95.47 & 86.00 & 26.60 & 4.00 & 4.50 \\
\hline 2 & Volcan De Tirajana & 710 & 97.22 & 88.70 & 26.17 & 3.40 & 7.06 \\
\hline 3 & Bencomo Express & 710 & 95.47 & 81.40 & 26.17 & 3.70 & 4.26 \\
\hline 4 & Normandie Express & 717 & 97.22 & 83.76 & 26.17 & 3.43 & 4.57 \\
\hline 5 & Hai Xia Hao & 717 & 97.22 & 82.80 & 26.17 & 3.43 & 4.57 \\
\hline 6 & Dublin Swift & 721 & 101.40 & 85.20 & 26.65 & 4.30 & 7.32 \\
\hline 7 & T\&T Spirit & 721 & 97.22 & 81.60 & 26.17 & 3.19 & 4.57 \\
\hline 8 & Turgut Ozal & 750 & 86.60 & 75.36 & 24.00 & 3.29 & 7.30 \\
\hline 9 & Adnan Menderes & 750 & 86.60 & 75.36 & 24.00 & 3.29 & 7.30 \\
\hline 10 & Milenium Dos & 755 & 98.00 & 83.96 & 26.17 & 3.44 & 4.82 \\
\hline 11 & Bentago Express & 755 & 96.00 & 81.00 & 26.17 & 3.97 & 4.26 \\
\hline 12 & Swift 1 & 758 & 98.00 & 86.00 & 26.17 & 3.22 & 4.60 \\
\hline 13 & Alboran & 800 & 92.00 & 81.00 & 26.17 & 3.70 & 4.26 \\
\hline 14 & Manannan & 800 & 92.00 & 81.40 & 26.17 & 3.70 & 4.26 \\
\hline 15 & Bonanza Express & 838 & 92.00 & 86.00 & 26.00 & 3.70 & 4.26 \\
\hline
\end{tabular}

by Molland et al., [20], and Millward, [21]. Souto-lglesias et al., [22], experimented with the catamaran wave system for the CFD Validation. In other research, Souto-Iglesias et al., [23], conducted an experimental assessment of interference resistance for a Series 60 catamaran. Brouglia et al., [24], study the effect of hull clearance on catamaran resistance, trim, and shrinkage.

The study on the sea-keeping behaviour of catamaran can be found in several papers. Kogan [25] was the first to do theoretical research of catamaran motion interaction with waves. Lee [26] presented an experimental and theoretical study of catamaran motions and load in head sea conditions. The first study of catamaran motion in waves and the added resistance was conducted by Faltinsen et al. [27]. The more recent papers focused on catamaran motion in waves numerically and experimentally can be found in Castiglione et al., [28], was conducted the numerical investigation of catamaran sea-keeping behaviour in regular head waves. Bouscasse et al., [29], have investigated the fast catamaran sea-keeping behaviour advancing in the head sea, [30]. Piscopo et al., [31], investigated the overall motion sickness incidence to the wave-piercing catamaran. Pandey et al., [32], study on the turning manoeuvre performance of catamaran surface vessel. Davis et al., investigated the slamming wave impacts on the wave-piercing catamarans.

According to the articles, most catamaran hulls have better rolling performance and transverse stability than the monohull design. The peak frequency of catamaran heave motion is practically constant with speed. The total heave force is achieved at the maximum wave radiation because the wave excitation force does not have a peak value. In the pitch motion, the appearance of both humps was perceptibly affected by the advancement speed. The maximum response has occurred when the wave excitation moment is ultimate (for $\lambda / L=1.33$ ), and the top of wave radiation moment is achieved (at resonance). However, disagreement with the conclusion could have occurred when different aspects were adopted. Thus the more investigation should be made.

Recently, the application and modification of catamarans hulls were made to support marine activities such as fast transportation, surveillance, leisure, and sports. In 2012, the Spearhead-class expeditionary fast transport (EFT) was developed by the US Navy to acquire an exceptional performance such as a higher service speed, shallow depth vessels for rapid intra-theatre transport, and reconfigurable as a troop transport infantry battalion. The

aluminium twin hull catamaran has four diesel engines to reach the maximum speed of 43 knots. The new generation of the Spearhead-class (USNS Newport) was delivered in 2020, [33]. Incat Tasmania introduced wave-piercing passenger ferries. Through the years of innovation, the vessel design becomes more efficient, bigger, and better stability in the rough sea. The wavepiercing passenger catamaran with the deadweight of 1000 tons, 900 passengers, and the cruising speed of 38 knots was delivered to Virtu Ferries in 2019 [38]. Otherwise, the development of catamaran hull form also can be found for the leisure boat, [34], fishing boat, [35], research boat, [36], and livestock carrier, [37].

This paper primarily implemented the catamaran hull for the fish processing vessel, which is operated on the domestic fishing ground in the Indonesia economic exclusive zone. After the hull form geometry was obtained, the proposed hull form performance is assessed, specifically in the case of resistance, intact stability, and sea-keeping behaviour. Furthermore, the comparison of the proposed catamaran hull with the previously developed monohull, [12], is conducted regarding the fish processing vessel requirement during the fishing operation.

\section{PRELIMINARY CATAMARAN HULL FORM DEVELOPMENT / Razvoj idejnog projekta za oblik trupa katamarana}

As developed for fish processing vessels, the catamaran hull form aims to achieve a worthy performance for fishing operations regarding better stability, resistance, and sea-keeping, instead of generating the hull performance to achieve fast maximum speed. The initial stage is to determine the principal dimension of the boat hull form. The existing catamaran boat was collected for creating the linear regression equation model, Table 1 . Since most of the collected existing catamaran is high-speed craft, the linear regression model only was used to determine the parent model principal dimension. The deadweight of the parent model was defined as large as 750 deadweight tons (DWT). Then, the linear regression generated the main dimensions of the parent hull model. Regarding the majority fishing activities capacity and the fishing ground distance in Indonesia, the hull geometry of the proposed FPV was obtained through the modification/conversion of the generated parent hull model.

The linear regression equation model was built for representing the relation of the given deadweight capacity with the other 
principal dimension such as length between perpendicular (LBP), Breadth (B), Draught (T), and Height of the hull (D), see Table 2. Those principal dimensions were adopted as the length, breadth, draught, and height of the proposed FPV hull. Furthermore, the proposed FPV hull geometry has been generated by enlarging the displacement to achieve the deadweight capacity and service speed requirement. Therefore the parent model hull was converted from 750 deadweight tons to the catamaran hull with 1800 deadweight tons and a service speed of 17 knots.

The next stage of the design process is designing the demi hull. The principal dimension of the vessel was used to select the parent hull as an initial reference for exploring the lines of the demi hull. The parent model is then transformed by configuring the block coefficient while the other dimension such as LBP and B remains constant. The result of the modification generated similar displacement, which can be seen in Table 3. Moreover, the design transformation from the parent model to the modified hull is presented in Fig. 2. Then, the principal dimension of the developed catamaran hull form can be seen in Table 4 .

Table 2 The linear regression equation to determine the parent model principal dimension

Tablica 2. Jednadžba linearne regresije za utvrđivanje glavnih dimenzija osnovnog modela

Principal Dimension Linear Regression Equation

Length Between Perpendicular (L) $L=91.704-0.007736$ (DWT)

Breadth (B) $\quad B=28.0054-0.00278(D W T)$

Draught ( $\mathrm{T}) \quad T=3.494+0.00012(D W T)$

Height $(\mathrm{H}) \quad H=11.624-0.00861(D W T)$

Table 3 The configuration of the block coefficient and displacement of the proposed FPV hull form Tablica 3. Konfiguracija blok koeficijenta i istisnina predloženog FPV oblika trupa

\begin{tabular}{|c|l|c|c|c|c|}
\hline No & Hull series & CB & LOA $(m)$ & B (m) & Displacement (ton) \\
\hline 1 & Hull 1 & 0.590 & 94.70 & 25.60 & 4382 \\
\hline 2 & Hull 2 & 0.595 & 94.70 & 25.60 & 4428 \\
\hline 3 & Hull 3 & 0.600 & 94.70 & 25.60 & 4453 \\
\hline 4 & Hull 4 & 0.605 & 94.70 & 25.60 & 4494 \\
\hline 5 & Hull 5 & 0.610 & 94.70 & 25.60 & 4539 \\
\hline 6 & Hull 6 & 0.620 & 94.70 & 25.60 & 4613 \\
\hline 7 & Hull 7 & 0.625 & 94.70 & 25.60 & 4662 \\
\hline 8 & Hull 8 & 0.630 & 94.70 & 25.60 & 4690 \\
\hline 9 & Hull 9 & 0.635 & 94.70 & 25.60 & 4763 \\
\hline 10 & Hull 10 & 0.640 & 94.70 & 25.60 & 4778 \\
\hline
\end{tabular}

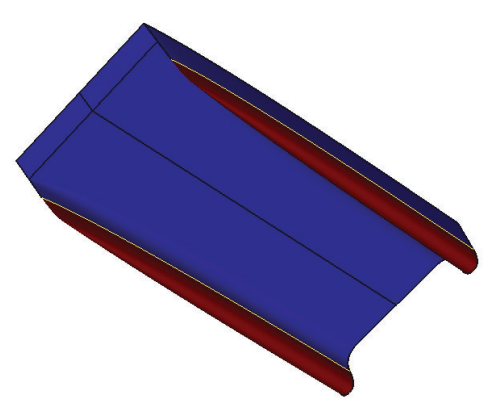

[a]

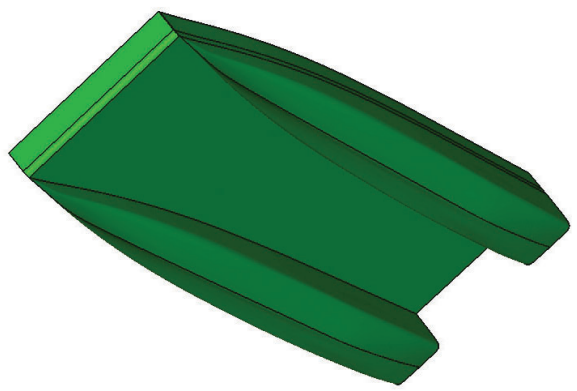

[b]

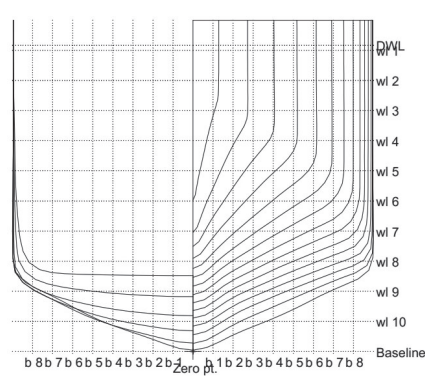

[c]

Figure 2 The hull design transformation: [a] the parent model; [b] the modified hull form; [c] the body plan of modified demi hull Slika 2. Transformacija dizajna trupa: [a] osnovni model; [b] modificirani oblik trupa; [c] bokocrt modificiranog polutrupa 
demi-hulls has influenced the vessel total resistance. Therefore, understanding the resistance component breakdown is essential knowledge to obtain an accurate estimation result. In estimating the total resistance, the calculation procedure should be made to determine the total resistance coefficient $(\mathrm{Ct})$ and the interference of the wave resistance. Otherwise, the catamarans wetted surface area has remained constant because the effect of hydrodynamic lift force on the high Froude number is not included. The empirical formula that was defining the total resistance coefficient is presented in Eq. 1 [10].

$$
C t=(1+\beta k) C f+\tau C w
$$

Where $(1+\beta k)$ is known as viscous form factor, $C f$ is friction resistance coefficient which is obtained from the skin friction formula from ITTC-1957, $\left(C_{F}=0.075 / \log \left(R_{N}-2\right)^{2}\right)$, $\tau$ is wave resistance interference factor, and $C W$ is the wave resistance coefficient, which is calculated using the slender body method with viscous form factor using Molland Algorithm, [13]. The viscous form factor $(1+\beta k)$ was determined in Eq. 2. Furthermore, the wave resistance interference factors $(\tau)$ as regards the Froude number (Fr) were determined in Eq. 3 to Eq.8, $[38,39]$. Where $L$ is the length between perpendiculars of the catamaran vessel, $\mathrm{Vol}$ is the displacement volume of the submerged body, $\beta$ is the viscous resistance interference factor, $k$ is the hull form factor. In estimating the wave interference factor on the required Froude number, the B-Spline interpolation method is used. The calculation result of the wave interference factor is presented in the next section.

Furthermore, the result of the viscous form factor according to the spacing demi hull ratio $(S / L)$ is presented in Table 4 . Once the total resistance coefficient $(C t)$ was obtained, the total catamaran resistance can be determined using the total hull resistance $\left(R_{T}\right)$ formula, Eq. 9 . Where $S$ is the wetted surface area of the submerged body, $\rho$ is the fluid density, and $V s$ is the vessel speed. The equation that was used for the estimation of the catamaran hull resistance is presented as follows:

- The equation of wave form factor:

$$
(1+\beta k)=3.03\left(L / \mathrm{Nol}^{1 / 3}\right)^{-0.4}+0.016(\mathrm{~s} / \mathrm{L})^{-0.65}
$$

- The equation of wave interference resistance factor according to the Froude number:

$$
\begin{aligned}
& F r=0.19, \text { then } \tau=0.068(\mathrm{~s} / \mathrm{L})^{-1.38} \\
& F r=0.28, \text { then } \tau=0.359(\mathrm{~s} / \mathrm{L})^{-0.87} \\
& F r=0.37, \text { then } \tau=0.574(\mathrm{~s} / \mathrm{L})^{-0.33} \\
& F r=0.47 \text { then, } \tau=0.790(\mathrm{~s} / \mathrm{L})^{-0.14} \\
& F r=0.56 \text { then, } \tau=0.504(\mathrm{~s} / \mathrm{L})^{-0.31} \\
& F r=0.65 \text { then, } \tau=0.501(\mathrm{~s} / \mathrm{L})^{-0.18}
\end{aligned}
$$

The equation of total hull resistance:

$$
R_{T}=0.5 \rho S C t V s^{2}
$$

Table 4 The Developed Catamaran Hull Viscous Form Factor Tablica 4. Faktor viskoznog oblika razvijenog trupa katamarana

\begin{tabular}{|c|c|}
\hline$S / L$ & $1+\beta k$ \\
\hline 0.17 & 1.5539 \\
\hline 0.20 & 1.5488 \\
\hline 0.30 & 1.5383 \\
\hline 0.40 & 1.5323 \\
\hline
\end{tabular}

\subsection{Intact Stability Performance Calculation / Izračun stabiliteta}

The intact stability calculation was made to define the vessel hull ability to return to its initial position when the wave load is acted as an external load. As a response to the exerted external load, the vessel hull has changed its initial position from the even keel condition to the heel or pitch condition. The stable vessel hull will be able to return to the initial position (even keel) because the positive righting moment is generated due to the centre buoyancy is shifted and conducted the righting lever arm (GZ) during the heeling position. However, the negative righting moment is produced on the unstable hull.

The calculation of the intact stability was begun by calculating the shifted centre buoyancy in each of the heeling angle conditions to generate the cross curve of stability. Furthermore, the GZ curve was derived from the set of the cross curves $(K N)$ and the centre of gravity height $(K G)$, when the distance of point $G$ and point $Z$ was obtained using the formula in Eq. 10 , where $\varphi$ is the heel angle.

$$
G Z=K N-K G \times \sin (\varphi)
$$

The shape of the hull influences the generated $G Z$ length, and it can be represented by the height of the metacentre (GM). The metacentre is an imaginary point on the intersection of the vertical line of the heeled centre of buoyancy with the original one, Figure 3. A stable hull should have a positive metacentric height $(G M)$. The metacentric height is positive when the metacentre point $(M)$ is above the centre of gravity point $(G)$. Furthermore, the water plane inertia moment and the hull displacement determine the metacentre position.

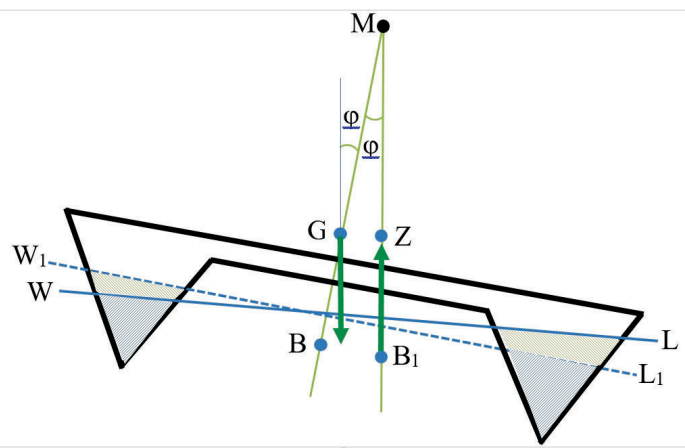

Figure 3 Illustration of the righting lever arm and metacentre point of the vessel.

Slika 3. Prikaz poluge za ispravljanje i metacentra broda

The intact stability performance was assessed with the stability criteria. The stability criteria that were adopted for the catamaran hull are the stability criteria for a fishing vessel from FAO, [40], IMO A.749 (18) code on intact stability, [41], and HSC Code 2000-MSC 97(73), [42]. The HSC code was adopted since the developed catamaran hull is categorized as a multihull vessel. The IMO stability criteria are commonly used for all types of boats. However, the IMO criteria for fishing vessels are also being used to assess the developed catamaran hull. Since there are three kinds of standard criteria, the combined stability criteria are adopted to evaluate the developed catamaran hull form. The combined stability criteria are described as follow:

1. The area under $\mathrm{GZ}$ curves up to $30^{\circ}$ angle of heel not less than $3.151 \mathrm{~m}$-rad

2. The area under $\mathrm{GZ}$ curves up to $40^{\circ}$ or flooding angle of heel not less than $5.156 \mathrm{~m}$-rad

3. The area under GZ curves from $30^{\circ}$ up to $40^{\circ}$ or flooding angle of heel not less than $1.718 \mathrm{~m}$-rad

4. The initial metacentric height (GM0) not be less than $350 \mathrm{~mm}$. 
5. The angle of the maximum righting lever arm (GZmax) not less than $10^{\circ}$ (for multihull)

6. The righting lever arm (GZ) should be at least $200 \mathrm{~mm}$ at the heel angle greater than $30^{\circ}$

\subsection{Sea-keeping Performance Calculation / Izračun ponašanja na moru}

The estimation of sea-keeping behaviour depends on the environment of the fishing ground and the criteria used to ensure that the fishing operation is appropriately accomplished. Therefore, the sea-keeping analysis is more complicated than estimating resistance to achieve the required vessel speed. The motion response of the vessel to the environmental condition is the function of the wave spectrum, and the hull geometry characteristics include the weight distribution. Therefore, as important as accurate hull geometry, the suitable wave spectrum was selected to represent the sea environment. The wave spectrum represents the irregular sea that was adopted to define the sea environment during the sea-keeping analysis. Many kinds of existing wave spectrum are usually implemented, such as Pierson-Moskowitz Spectrum, Bretschneider (ITTC) Spectrum, JONSWAP Spectrum, and Ochi-Hubble Spectrum.

Several references can be found to describe the domestic sea condition in Indonesia. Kurniawan and Khotimah [44], obtained that the highest wave, on the Asian monsoon, occurs in the South China Sea, and the Pacific Ocean may reach more than 3 meters. The Indian Ocean and Arafura Sea highest wave may reach more than 2.5 meters on the Australian monsoon. However, the domestic sea of Indonesia is not prone to high tides. On the domestic sea, the significant wave height is rarely higher than 1.7 meters, and a slightly exceeding 2 meters can be found in the southern part of Java Island.

Regarding the selection of the wave spectrum, the JONSWAP spectrum was adopted for the Pacitan and Meulaboh coast, located on the Western part of Sumatra Island and the Southern part of Java Island [46]. The ITTC spectrum was chosen for the inter-island waters in the Indonesia territorial sea [47]. The other study present that the Ochi-Hubble is a suitable spectrum since the wave spectrum of Indonesia territorial sea has double peaks on the measurement result, [51], [52]. Amongst the wave spectrum alternatives, this study was selected the JONSWAP spectrum with a significant wave height of $3 \mathrm{~m}$, a zero-crossing period of 6 , and a peak enhancement factor of 3.30. Meanwhile, it is commonly applied to the enclosed water wave conditions in which the fishing ground is located. Therefore, the JONSWAP spectrum is suitable to represent the Indonesian archipelagic waters. The equation of the JONSWAP spectrum can be seen in eq. (11), where is the fetch and is the wind speed $10 \mathrm{~m}$ above the sea level.

$$
S(\omega)=\alpha g \omega^{-5} e^{\left[-\frac{5 \omega}{4 \omega_{m}}\right]^{-4}} \gamma^{\delta}
$$

Where,

$$
\begin{aligned}
& \gamma=3.3 ; \delta=-\frac{\left(\omega-\omega_{m}\right)^{2}}{2 \sigma^{2} \omega_{m}^{2}} ; \quad \alpha=0.076 \bar{x}^{(-0.22)} ; \\
& \bar{x}=\frac{g x}{U^{2}} ; \quad \sigma=\left\{\begin{array}{l}
0.07 ; \omega \leq \omega_{m} \\
0.09 ; \omega>\omega_{m}
\end{array} ; \quad \omega_{m}=\frac{2 \pi \bar{f}_{m} g}{U} ; \bar{f}_{m}=3.5 \bar{x}^{-0.33}\right.
\end{aligned}
$$

\section{RESULTS AND DISCUSSION / Rezultati i rasprava}

\subsection{Resistance Characteristics / Karakteristike otpora}

The configuration of demi hull distance on the proposed hull form was examined through the numerical calculation to estimate their practical operability. According to the results, Fig. 4 shows that the wave resistance coefficients have shown non-fluctuated value on the Froude number of 0 to 0.22 and fluctuated in the range of 0.22 to 0.65 . Fortunately, most of the operational speed of the developed vessel is originated in the non-fluctuated value. In the operating speed range, the maximum point of the wave resistance coefficient was seen on the Froude number around 0.26 0.27. Then the wave resistance coefficient was significantly dropped when achieving the maximum speed of 17 knots. Regarding the influence of demi hull spacing ratio $(s / L)$, it is indicated that the larger the demi-hull spacing, the bigger the tendency to reduce the value of the coefficients, especially on the high Froude number condition.

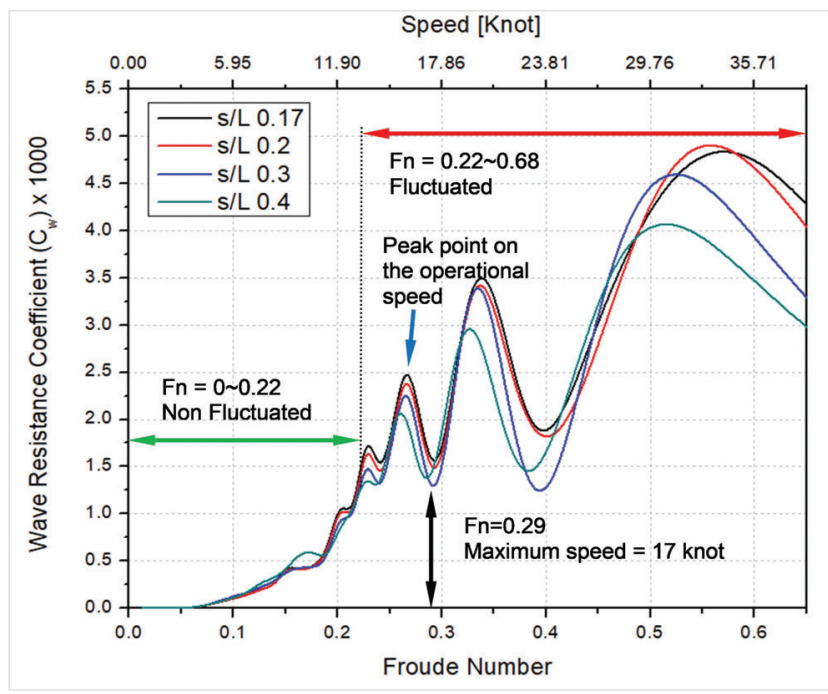

Figure 4 Catamarans wave resistance coefficient using the slender body method (Cw)

Slika 4. Koeficijent otpora na valove katamarana uz uporabu metode vitkog tijela

Since catamarans are twin-hull vessels, the wave interference phenomena might occur and undoubtedly increased vessel resistance. The influence of the wave interference was defined as the wave interference resistance that is presented as the wave interference resistance factor ( $\tau)$. Fig. 5 shows that the behaviour of the wave interference resistance factor was described on the two kinds of zones that are defined as the escalation zone and the diminishing zone. The escalation zone has shown the trend of the increment of the resistance factor. The influence of demi hull spacing was significantly identified that the larger demi hull spacing was reduced the wave interference. The larger demi hull spacing also tends to shift the peak point to the higher Froude number. Therefore, the hull with $\mathrm{s} / \mathrm{L}=0.4$ has achieved the peak point on $\mathrm{Fr}=0.46$. Nevertheless, it can be seen that the escalation trend generally occurs in the Froude numbers below 0.3 . The diminishing zone was seen when the resistance coefficient started to decline and gradually decrease during the increase of the Froude number. 


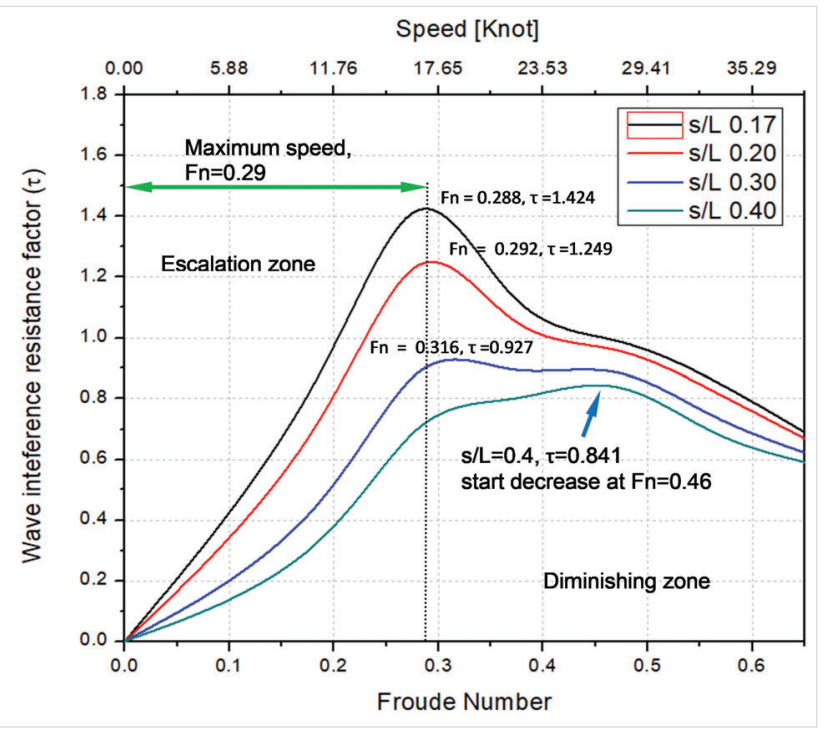

Figure 5 B-spline interpolation to estimate the wave interference resistance factor $(\tau)$

Slika 5. B-spline interpolacija za procjenu faktora utjecaja valova $(\tau)$

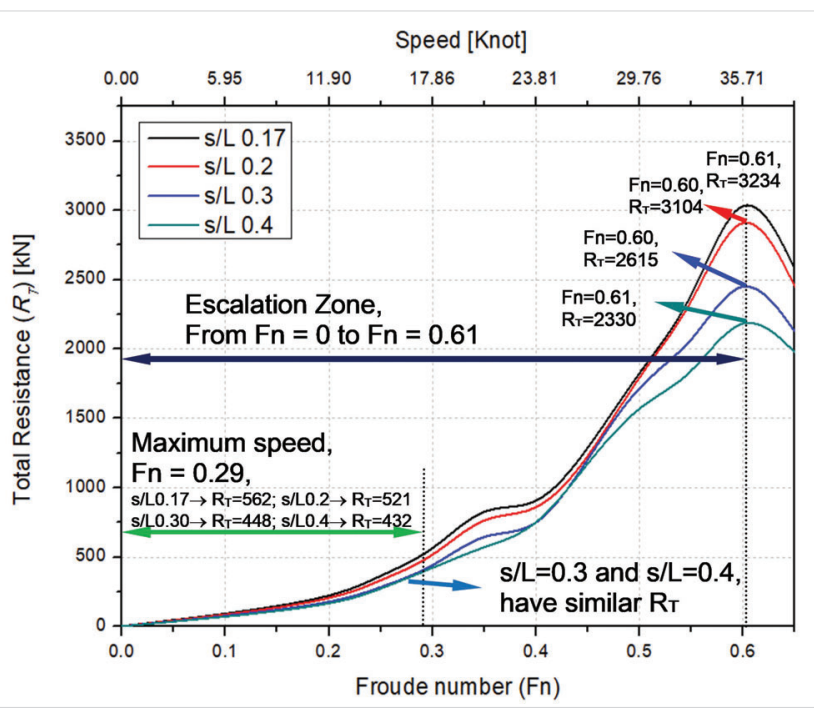

Figure 6 The total resistance (RT) of the catamarans hull form Slika 6. Ukupni otpor (RT) oblika trupa katamarana

All of the factors used to estimate the total resistance were influenced by the demi hull spacing ratio. The total resistance coefficient have been defined as the sum of viscous resistance coefficient and the wave pattern resistance coefficient. The viscous resistance coefficient is determined by the viscous form factor, Table 4. While the wave pattern coefficient is the multiplication of the wave interference factor and the wave resistance coefficient. Regarding the calculation results, it can be seen that the $s / L=0.4$ have smallest viscous form factor $(1+\beta k)$, wave interference factor $(\tau)$, and the wave resistance coefficient $(\mathrm{CW})$. Therefore the total resistance of the higher demi hull spacing is lower than the others, Fig. 6 . The $\mathrm{s} / \mathrm{L}=0.4$ can reduce the total resistance by about $23.13 \%$ of the $s / L=0.17$ during the operational speed $(\mathrm{Fr}<0.3)$. However, the reduction is not significantly recognized when the Froude number is low $(\mathrm{Fr}<0.1)$ and the demi hull spacing ratio is larger than 0.3. The total resistance has an escalation trend until the vessel speed has reached 35.71 knots $(\mathrm{Fr}=0.61)$. These phenomena might have occurred because the wave interference factor and the wave resistance coefficient have shown a significant decrement trend in the large Froude number, Fig. 4 and Fig.5.

Since the catamaran hull form was made as an alternative hull form for the fish processing vessel, the comparison of the catamaran hull resistance behaviour with the previously developed monohull was conducted. Figure 7 shows that the catamarans have a smaller wave resistance coefficient than the monohull on the low service speed ( $V s<11.2$ knots). Nevertheless, within the moderate service speed of 11.2-21.5 knot, the monohull performed the lower wave resistance coefficient. It can be seen that the monohull has a slight slope than the catamaran hull in the low-speed condition. The slope is gradually increased at a moderate speed, and it turns into an extreme slope at high speed ( $V s>21.5$ knots), while the catamaran was shown contradictory. It can be concluded that the catamarans hull have an optimum wave-making resistance on low-speed and high-speed conditions.

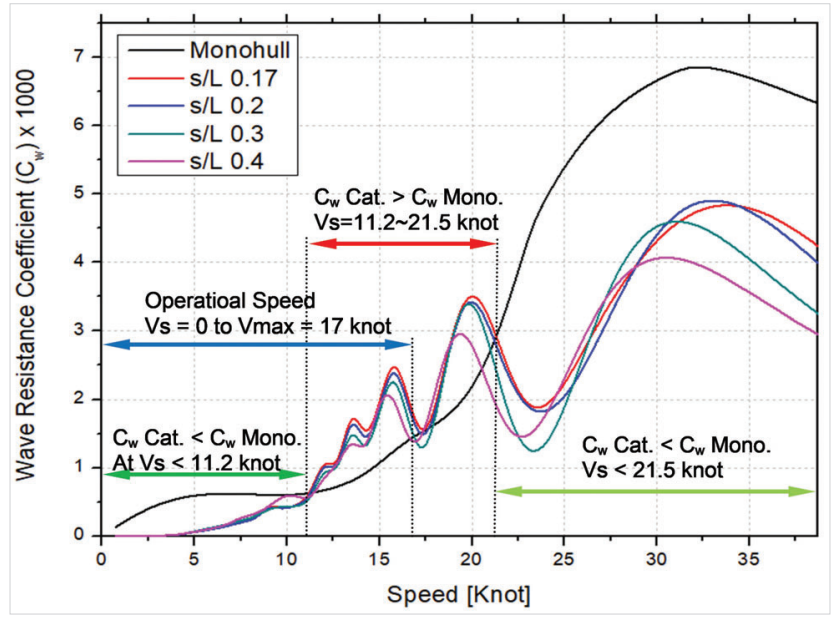

Figure 7 Comparison of the wave resistance coefficient between the catamaran and the monohull Slika 7. Usporedba koeficijenta otpora na val između katamarana i višetrupca

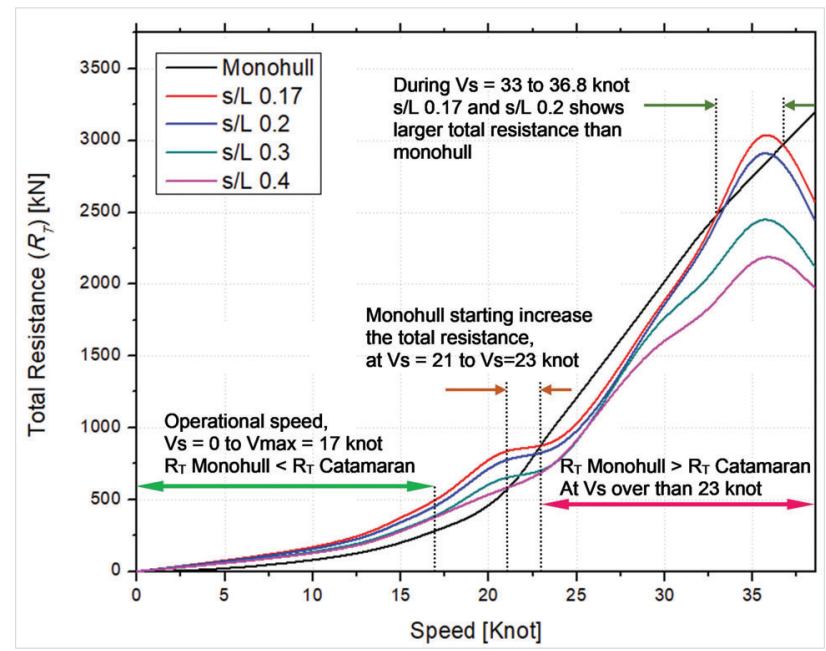

Figure 8 Comparison of the total resistance coefficient between the catamarans and the monohull

Slika 8. Usporedba koeficijenta ukupnog otpora između katamarana i višetrupca

Although the catamarans hull presented the better wavemaking resistance, the catamarans hull total resistance were not 
usually lower than the monohull. It might be happened because the other resistance component, such as the wave interference coefficient and the additional wetted surface area due to the twin-hull design, can increase the hull total resistance. Figure 8 presents that the catamaran hull has larger total resistance than the monohull within the operational speed ( $V s \leq 17$ knots) and stays larger until the service speed reaches 21 knots. The influence of the wave-making resistance on the monohull was found on the high-speed condition. Therefore, the catamaran hull showed better total resistance on the service speed over than 23 knots. It can be concluded that the developed catamarans hull have better total resistance performance than the monohull at the relatively high service speed.

\subsection{Intact Stability Characteristics / Karakteristike stabiliteta}

The intact stability is an essential performance for the design and operation of ships and boats. The GZ curves were generated to describe the characteristics of ship stability. Then, the GZ curve differences can be quantified and assessed by comparing them with the combined stability criteria. Comparing the developed catamaran hull with the monohull is also conducted to present the reserve stability of each developed hull. According to the calculation result, Fig. 9, all of the catamaran hull designs have shown a positive righting lever arm. The influence of demi hull spacing has demonstrated that the larger spacing generates the large righting arm (GZ). Therefore, the $\mathrm{s} / \mathrm{L}=0.4$ produces the maximum righting arm (GZ) of $16.08 \mathrm{~m}$ which is 3.74 times larger than the $\mathrm{s} / \mathrm{L}=0.17$ with the righting arm of $3.39 \mathrm{~m}$. Furthermore, the influence of the demi hull spacing also can be found on the shifted heeling angle at which the maximum arm is generated. The heeling angle on the maximum GZ of the $s / L=0.4\left(14.1^{\circ}\right)$ is $43.6 \%$ smaller than the $\mathrm{s} / \mathrm{L}=0.17\left(25^{\circ}\right)$. The larger righting arm on the smaller heeling angle might generate a stiff roll motion which might cause sea-sickness. Fortunately, the catamaran design is a slender twin-hull that reduces the exciting wave effect on the roll motion.

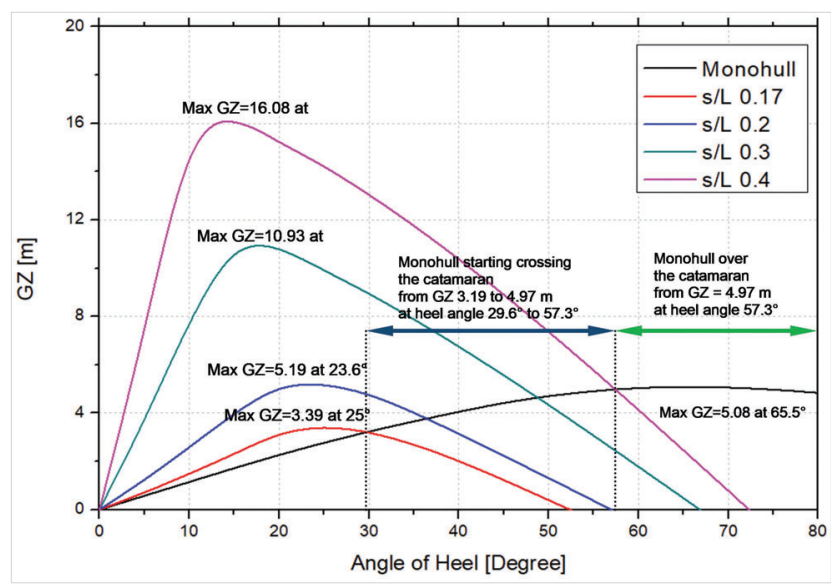

Figure 9 Intact stability curves of the catamarans and the monohull

Slika 9. Krivulje stabiliteta katamarana i višetrupca

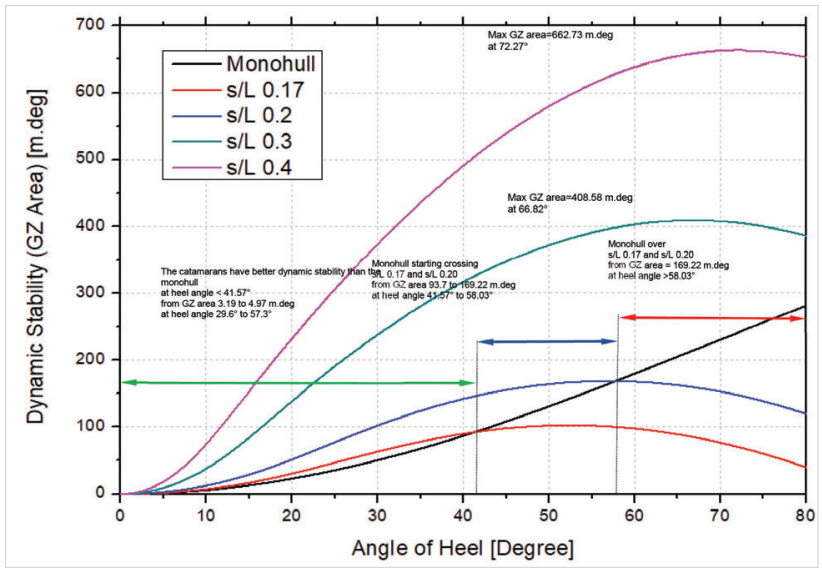

Figure 10 Dynamic stability curves of the catamarans and the monohull

Slika 10. Krivulje dinamičkog stabiliteta katamarana i višetrupca

Comparing with the monohull, Figure 9 shows that the catamaran hull has a larger righting arm than the monohull. The enormous hull breadth of the catamaran has generated the larger righting arm. Therefore, the $s / L=0.4$ is presented the GZ length significantly more significant than the monohull. Furthermore, the monohull showed a maximum $\mathrm{GZ}$ of $5.08 \mathrm{~m}$ at the angle of heel of $65.5^{\circ}$. The higher angle of maximum GZ and smaller righting arm (GZ) present a gentle roll motion that created good habitability during fishing operation. Otherwise, the monohull righting arm (GZ) was seen to cross the catamarans at the heel angle of $29.6^{\circ}$ to $57.3^{\circ}$. The monohull would have a larger righting arm than the catamarans at the heel angle over $57.3^{\circ}$ unless the down flooding angle has occurred below the heel angle.

Figure 10 also have shown that all of the catamarans have better dynamic stability than monohull at the heeling angle below $41.57^{\circ}$. Otherwise, the dynamic stability curve of the monohull was starting to cross the catamarans with $\mathrm{s} / \mathrm{L} 0.17$ and $\mathrm{S} / \mathrm{L} 0.20$ at the heeling angle of $41.57^{\circ}$ and $58.03^{\circ}$. This condition indicates that monohull dynamic stability is better than the catamarans with s/L 0.17 and s/L 0.20. However, the larger maximum $\mathrm{GZ}$ area still can be shown on the catamarans $\mathrm{s} / \mathrm{L} 0.30$ and $\mathrm{s} / \mathrm{L} 0.40$ at the heeling angle of $66.82^{\circ}$ and $72.27^{\circ}$, respectively.

According to the above description, both the catamaran and the monohull have a positive righting arm that produces an excellent intact static and dynamic stability for the FPV. Regarding the combined criteria, Table 5 shows that most of the catamarans offer a more significant value than the monohull at all requirements. It is indicated that the catamarans provide better intact stability than the monohull. In the case of dynamic stability, the catamarans also presented better dynamic stability at the heeling angle below $41.57^{\circ}$. Otherwise, the catamaran with $\mathrm{s} / \mathrm{L} 0.17$ and $\mathrm{s} / \mathrm{L} 0.20$ have lower dynamic stability than the monohull at the heeling angle larger than $41.57^{\circ}$ and $58.03^{\circ}$, respectively. Therefore, the monohull is still acceptable and reliable to be adopted as the FPV design because the monohull also has passed the combined criteria and has more considerable dynamic stability than the catamarans with s/L 0.17 and s/L 0.20, especially on the high heeling angle conditions. 
Table 5 Comparison of the catamaran and the monohull on the combined criteria Tablica 5 Usporedba katamarana i višetrupca prema kombiniranom kriteriju

\begin{tabular}{|c|c|c|c|c|c|c|c|}
\hline \multirow{2}{*}{ Combined Criteria } & \multirow{2}{*}{ Required } & \multicolumn{5}{|c|}{ Hull Forms Model } & \multirow{2}{*}{ Status } \\
\hline & & s/L 0.17 & s/L 0.20 & S/L 0.30 & s/L 0.40 & Mono hull & \\
\hline Area $0^{\circ}$ to $30^{\circ}$ & 3.151 m.deg & 63.43 & 102.3 & 237.6 & 373.4 & 50.50 & Passed \\
\hline Area $0^{\circ}$ to $40^{\circ}$. or Downflooding point & 5.156 m.deg & 90.01 & 142.2 & 316.3 & 490.8 & 87.02 & Passed \\
\hline Area $30^{\circ}$ to $40^{\circ}$. or Downflooding point & 1.718 m.deg & 26.58 & 39.9 & 78.7 & 117.4 & 36.52 & Passed \\
\hline Initial GM & $0.35 \mathrm{~m}$ & 7.93 & 13.7 & 39.8 & 76.5 & 6.59 & Passed \\
\hline Angle of GZ max & $10 \mathrm{deg}$ & 25.0 & 23.6 & 17.7 & 14.1 & 65.5 & Passed \\
\hline $\mathrm{GZ}$ at $30^{\circ}$. or greater & $0.2 \mathrm{~m}$ & 3.19 & 4.75 & 8.94 & 13.0 & 5.08 & Passed \\
\hline
\end{tabular}

\subsection{Sea-keeping Characteristics / Karakteristike ponašanja na moru}

The previous intact stability analysis is not an appropriate method to describe the dynamic phenomena of the vessel during the operational fishing activities. Therefore, the sea-keeping analysis was conducted to assess the motion characteristics against the sea-keeping criteria. The strip theory method was adopted for the calculation of the seakeeping performance of the developed vessel hull. The calculation result was presented as the response amplitude operator (RAO) of each motion of the developed vessel hull. The RAOs are transfer functions effectively used to determine the wave environment effect on the ship motion. Generally, the developed catamaran hull RAOs was made with the wave heading angle $90^{\circ}$ (Beam Sea), $135^{\circ}$ (Bow Quartering Sea), and $180^{\circ}$ (Head Sea) and the vessel speed of 17 knots. The calculations results of the RAOs and the motion spectral density were presented in Fig 11 - Fig.13 and Fig. 14 - Fig.16, respectively.

According to the calculation results, it can be seen that the heave and pitch motion response of all of the proposed catamarans is similar, Fig 11 and Fig. 12. It can be explained that the RAOs of heave and pitch motion response were influenced by the shape of the demi-hull. Otherwise, the heave and pitch motion responses were not affected by the demi hull spacing. Therefore, the same demi hull presented the same RAOs on both motions. The catamaran roll motion RAO has shown a variation of RAOs of each configuration of demi hull spacing. It is indicated that the ship motion was influenced by the demi hull spacing. Therefore, during the comparison with the monohull, Fig. 11-Fig.13 presented a single RAO line for the catamaran on the heave and pitch motions. Otherwise, the four graphics lines were found for the catamarans on the roll motion conditions.
During the beam sea condition, the catamarans presented a more significant response amplitude operator on the heave motion condition than the monohull, Fig. 11a. It is indicated that the beam sea wave load significantly influences the heave motion of the catamarans. Furthermore, it also can be said that the monohull has a larger heave motion damping than the catamarans. The phenomena can be explained by the magnitude of the heave motion damping is determined by the waterplane area on the baseline. Since the catamarans have a smaller waterplane area than the monohull, the catamaran heave motion damping is relatively low.

On the RAOs of pitch motion, both the vessel type was presented a small magnitude of response (RAO $<1)$, Fig. $11 \mathrm{~b}$. This calculation result has a good agreement with the theory that explained the pitch motion is not directly influenced by the beam sea unless the shifted centre of buoyancy due to the exciting heave motions have formed the pitch motion lever arm.

In Figure 11c, the behaviour on the roll motion was presented. It can be seen that the demi hull spacing has a significant influence on reducing the roll motion response. The more considerable demi hull distance has shown the smaller RAOs roll motion. Compare with the monohull, the RAO roll motion of the catamarans has shown a lower value. It can be determined that the catamarans have a more significant roll motion damping than the monohull. This result demonstrated that the catamarans had offered a better roll motion performance than the monohull, even though the intact stability calculation was shown a very large GZ that might generate the stiff roll motion. Furthermore, the larger demi-hulls distance can produce larger roll motion damping.

The next wave heading angle was Bow Quartering Sea $\left(135^{\circ}\right)$. Figure 12 presented that the catamarans have better heave and roll motion responses. It is found that the slender twin body of the catamarans effectively reduced the effect

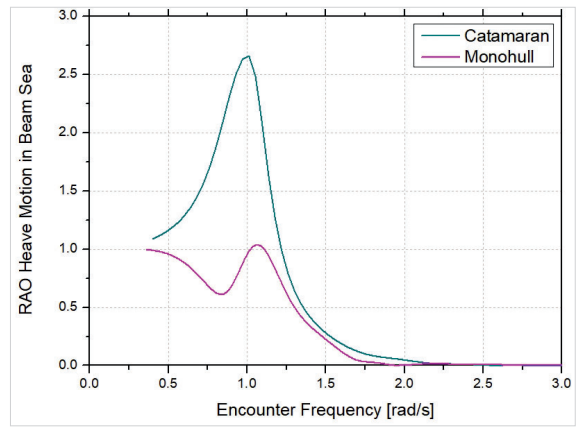

[a]

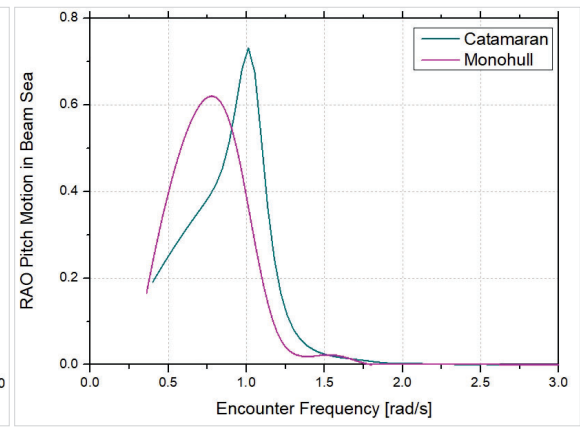

[b]

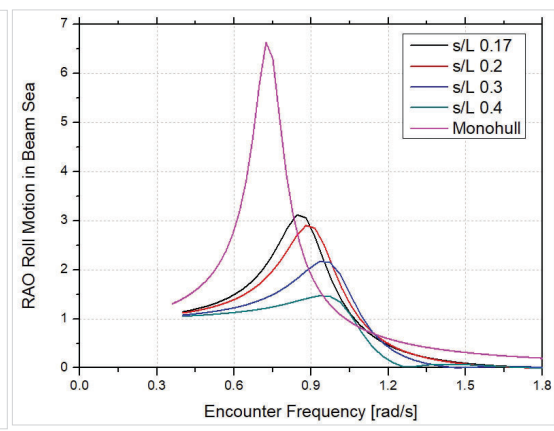

[c]

Figure 11 Comparison of the RAO of the catamarans and the monohull: [a] heave in Beam Sea; [b] pitch in Beam Sea; [c] roll in Beam Sea Slika 11. Usporedba RAO katamarana i višetrupca: [a] propadanje s valovima s boka; [b] posrtanje s valovima s boka; [c] valjanje s valovima s boka 


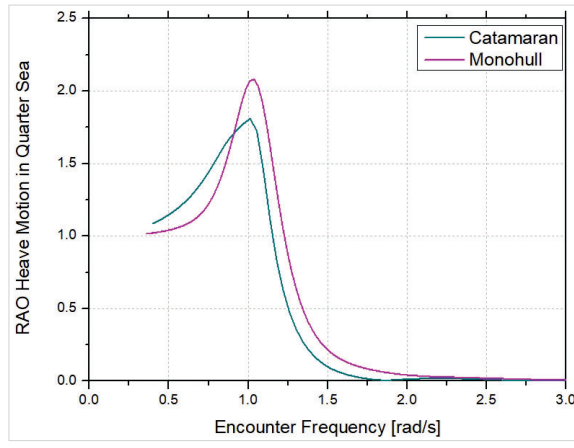

[a]

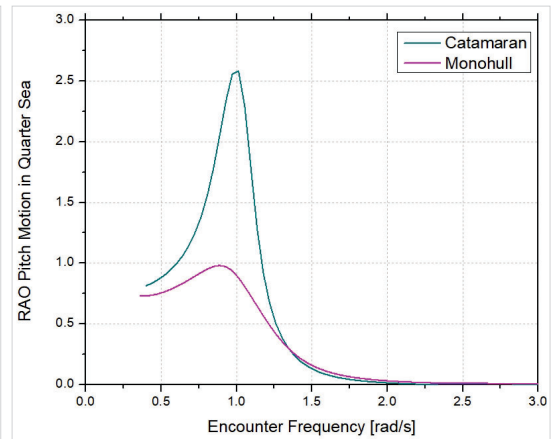

[b]

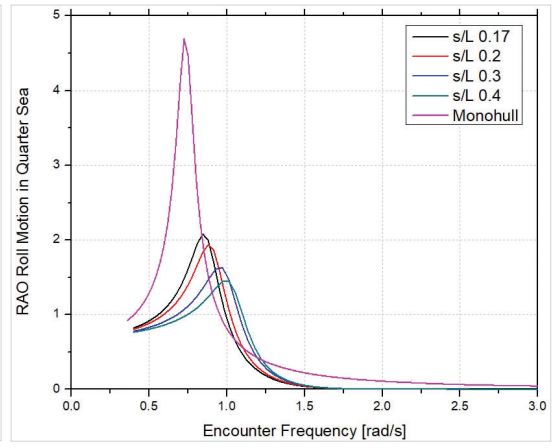

[c]

Figure 12 Comparison of the RAO of the catamarans and the monohull: [a] heave in Bow Quartering Sea; [b] pitch in Bow Quartering Sea; [c] roll in Bow Quartering Sea

Slika 12. Usporedba RAO katamarana i višetrupca: [a] propadanje s valovima s pramčanog boka; [b] posrtanje s valovima s pramčanog boka; [c] valjanje s valovima s pramčanog boka

of bow quartering wave load on both motion responses. However, the slender body conducted an enormous pitch motion response than the monohull. The phenomena can be explained that the slender bodies have slighter waterplane inertia that might generate a small pitch motion damping due to the external excitation load. Therefore, most multihulls that adopted a slender twin body, such as catamaran and SWATH, usually have an enormous pitch motion response. In the case of heave motion, the monohull RAO increased significantly and became more significant than the catamarans. This phenomenon might be occurred because of the significant reduction of the monohull damping ratio. Otherwise, the increased heading angle also tends to shift the heave motion natural frequency close to the wave frequency. The resonance effect might be occurred when the natural frequency equal to wave frequency.

Finally, the sea-keeping analysis of the catamarans was made on the wave heading angle of 180 degrees (head sea). Figure 13 shows that the catamaran motion response has occurred only on the heave and the pitch motion. Since the centre of gravity, the centre of buoyancy, and the centre of floatation have been determined to be located at the centreline. Consequently, the roll motion response of both vessel types due to the head wave load did not occur (zero). The changes of the centre of buoyancy position caused by the head wave were unable to conduct the righting moment because both of the vessels bodies have symmetrical geometry on the centreline. The centre of buoyancy was only shifted vertically and in line with the centre of floatation and gravity on the centreline. Regarding the heave and the pitch motion, Fig. 13 presented that the catamarans have smaller RAO heave motion than the monohull. The increment of the monohull RAO heave motion can also be explained that the increased heading angle has significantly reduced the damping ratio and shifted the heave motion natural frequency closer to wave frequency. Furthermore, the slender twin bodies have effectively reduced the influence of head wave load on the heave motion response. Otherwise, the slender bodies still have a negative effect on the pitch motion response due to the waterplane moment of inertia not as large as the monohull. Therefore, the monohull has shown a better RAOs pitch motion response than the catamarans, Fig. 13b.

In the case of the ship motion response due to the selected JONSWAP wave spectrum, almost all of the characteristics of the motion response spectral density have a similar tendency with the RAO curves of both vessel types, Fig 14 - Fig 16. However, the motion spectral density of the pitch motion in Beam Sea and the roll motion in Bow Quartering Sea have presented opposing characteristics with the RAO of the vessels motion. In Beam Sea, the monohull has a more significant pitch motion spectral density than the catamarans, Fig. 14b, while the pitch motion RAO shows that the monohull is smaller than the catamarans, Fig. $11 \mathrm{~b}$. This condition can be explained that most of the monohull pitch motion RAO values have transferred the larger magnitude of wave spectral density than the catamarans, Fig. 17. These conditions also describe the opposing characteristics of the catamarans roll motion spectral density in Bow Quartering Sea, Fig. 18.

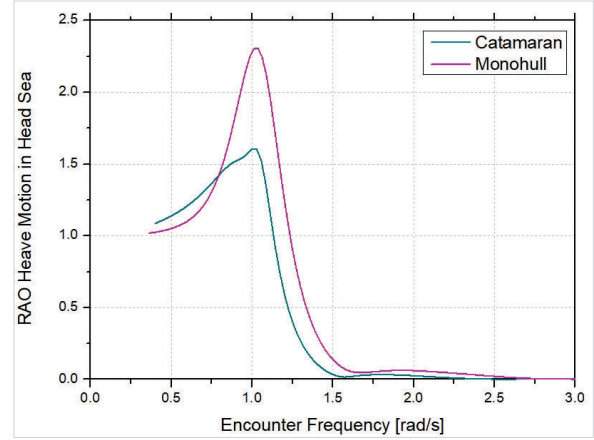

[a]

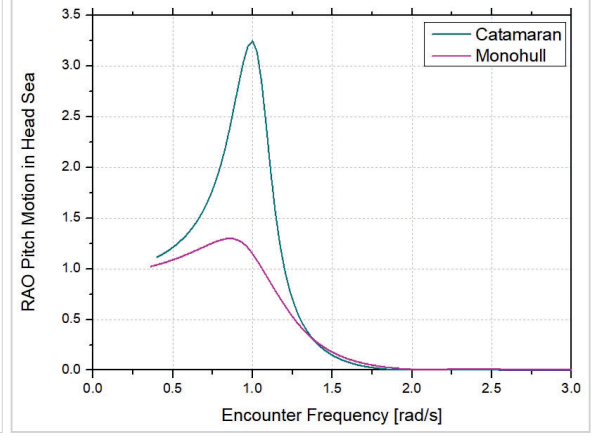

[b]

Figure 13 Comparison of the RAO of the catamarans and the monohull: [a] heave in Head Sea; [b] pitch in Head Sea Slika 13 Usporedba RAO katamarana i višetrupca: [a] propadanje s valovima s pramca; [b] posrtanje s valovima s pramca 


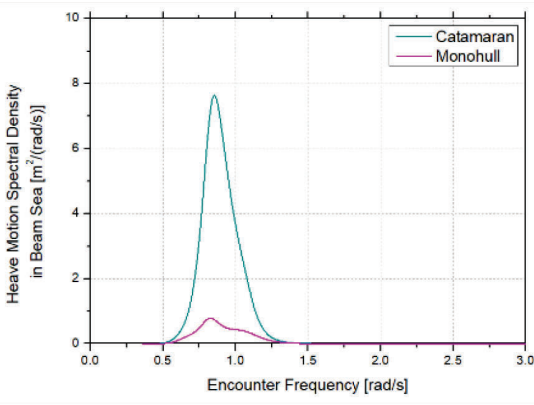

[a]

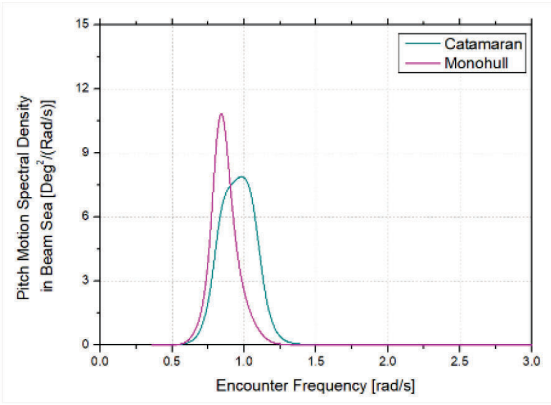

[b]

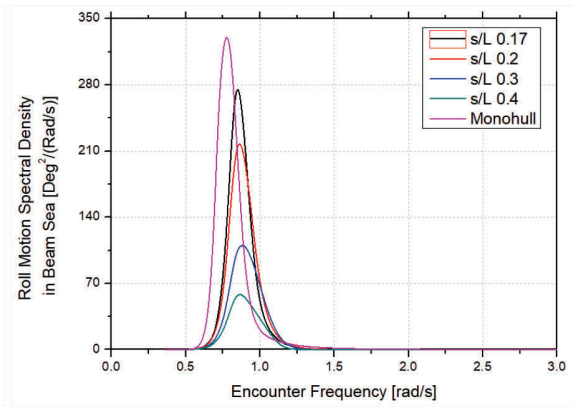

[c]

Figure 14 Comparison of the motion spectral density of the catamarans and the monohull: [a] heave in Beam Sea; [b] pitch in Beam Sea; [c] roll in Beam Sea

Slika 14. Usporedba spektralne gustoće kretanja katamarana i višetrupca: [a] propadanje s valovima s boka; [b] posrtanje s valovima s boka; [c] valjanje s valovima s boka

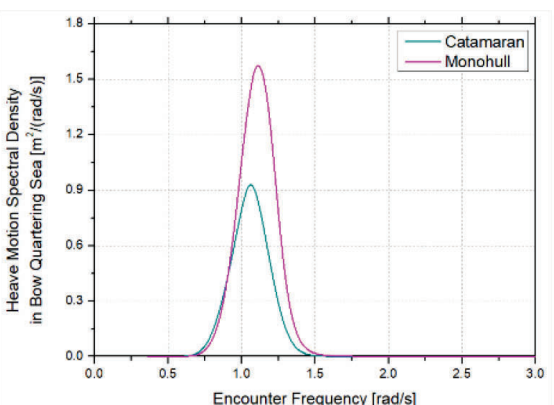

[a]

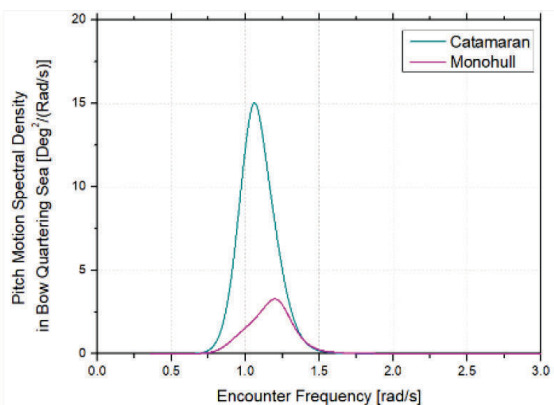

[b]

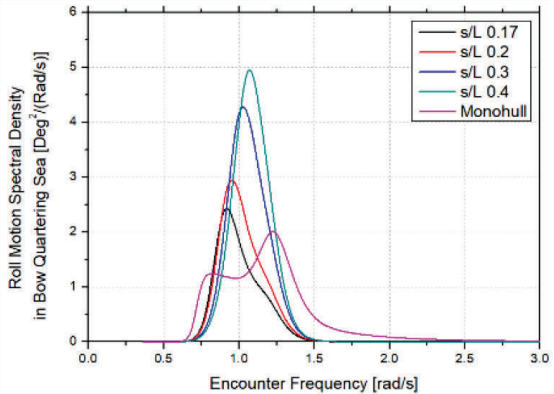

[c]

Figure 15 Comparison of the motion spectral density of the catamarans and the monohull: [a] heave in Bow Quartering Sea; [b] pitch in Bow Quartering Sea; [c] roll in Bow Quartering Sea

Slika 15. Usporedba spektralne gustoće kretanja katamarana i višetrupca: [a] propadanje s valovima s pramčanog boka; [b] posrtanje s valovima s pramčanog boka; [c] valjanje s valovima s pramčanog boka

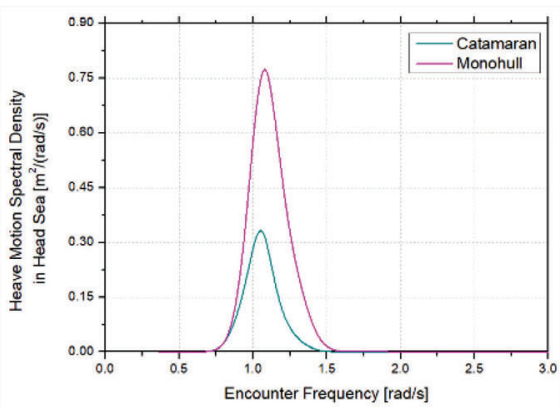

[a]

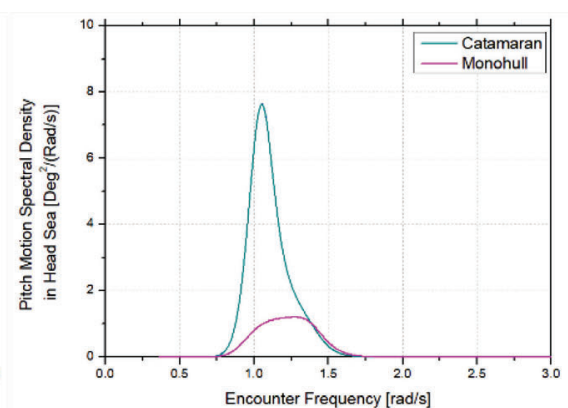

[b]

Figure 16 Comparison of the motion spectral density of the catamarans and the monohull: [a] heave in Head Sea; [b] pitch in Head Sea Slika 16. Usporedba spektralne gustoće kretanja katamarana i višetrupca: [a] propadanje s valovima s pramca; [b] posrtanje s valovima s pramca

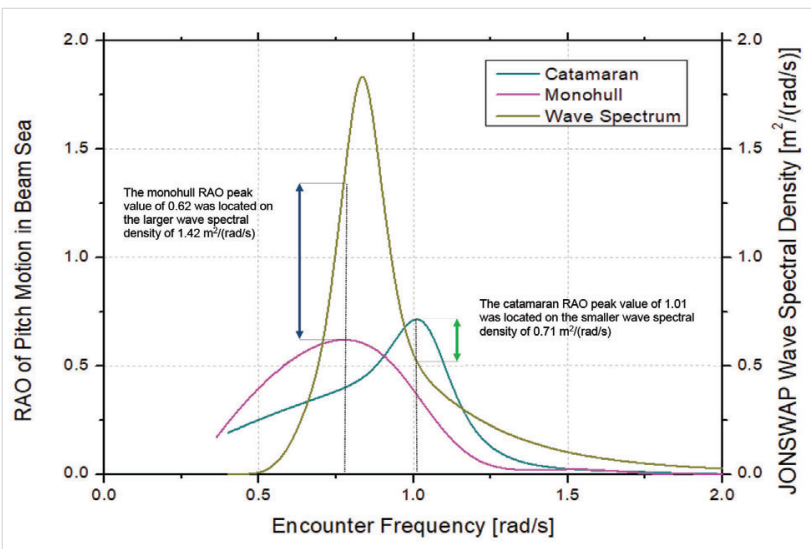

Figure 17 JONSWAP wave spectral density and pitch motion RAO of the catamarans and the monohull in Beam Sea Slika 17. JONSWAP spektralne gustoće vala i RAO propadanja katamarana i višetrupca s valovima s boka 


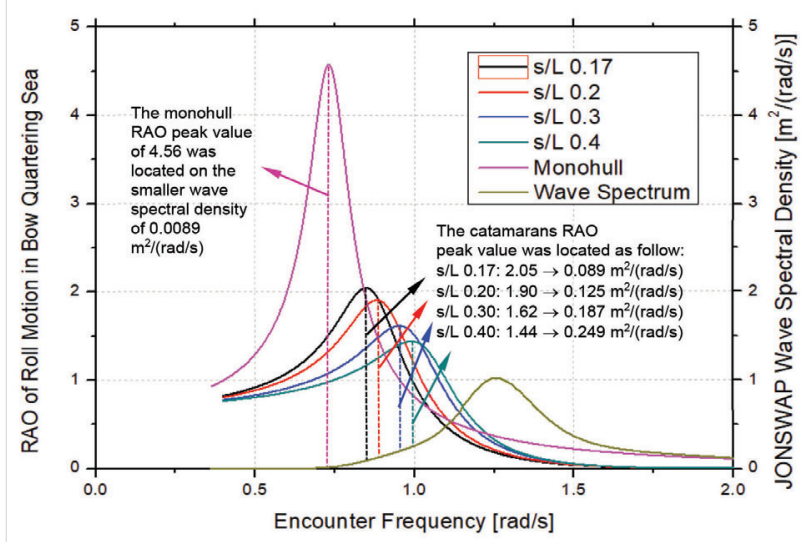

Figure 18 JONSWAP wave spectral density, the roll motion RAO of the catamarans,and the roll motion RAO of the monohull in Bow Quartering Sea

Slika 18. JONSWAP spektralne gustoće vala, RAO valjanja katamarana i $R A O$ valjanja višetrupca s valovima s pramčanog boka

According to the sea-keeping analysis, it can be seen that the catamarans hull forms able to improve the motion characteristics of the monohull. In the Beam Sea, the catamarans have presented a better pitch and roll motion than the monohull. In the Bow Quartering Sea, the catamarans have a better heave motion response. However, the roll motion catamarans have shown a higher magnitude than the monohull. Although the catamarans roll motion RAO has shown better characteristics than the monohull, the roll motion spectral density presented a contradictory result. This condition might be occurred because the RAO catamarans encounter frequency was close to the encounter frequency of the enormous magnitude of the wave spectral density. Therefore the catamarans have significantly increased the magnitude of roll motion spectral density. Furthermore, the larger demi-hulls distance could shift the roll motion RAO encounter frequency close to the encounter frequency of the wave spectral density. Consequently, the larger demi-hulls distance can increase the roll motion spectral density. In Head Sea, the catamarans have a better heave motion than the monohull. However, the catamarans have shown a higher pitch motion response because the slender body hull form has lower pitch motion damping than the monohull. The motion root means square results can be seen in Tables 6 to 8 .

Table 6 Comparison of the motion root mean square in Beam Sea

Tablica 6. Usporedba korijena srednjeg kvadrata kretanja na valovima s boka

\begin{tabular}{|c|c|c|c|c|c|}
\hline Motion Type & s/L 0.17 & s/L 0.20 & s/L 0.30 & s/L 0.40 & Monohull \\
\hline Heave Amplitude & 1.429 & 1.429 & 1.427 & 1.427 & 0.521 \\
\hline Heave Velocity & 1.289 & 1.290 & 1.287 & 1.287 & 0.481 \\
\hline Heave Acceleration & 1.203 & 1.204 & 1.201 & 1.201 & 0.473 \\
\hline Pitch Amplitude & 1.640 & 1.640 & 1.630 & 1.630 & 1.470 \\
\hline Pitch Velocity & 0.028 & 0.028 & 0.027 & 0.027 & 0.022 \\
\hline Pitch Acceleration & 0.027 & 0.027 & 0.027 & 0.027 & 0.020 \\
\hline Roll Amplitude & 7.150 & 6.860 & 5.380 & 3.890 & 7.930 \\
\hline Roll Velocity & 0.109 & 0.107 & 0.086 & 0.061 & 0.115 \\
\hline Roll Acceleration & 0.098 & 0.098 & 0.081 & 0.057 & 0.110 \\
\hline
\end{tabular}

Table 7 Comparison of the motion root mean square in Bow Quartering Sea

Tablica 7. Usporedba korijena srednjeg kvadrata kretanja na valovima s pramčanog boka

\begin{tabular}{|c|c|c|c|c|c|}
\hline Motion Type & s/L 0.17 & s/L 0.20 & s/L 0.30 & s/L 0.40 & Monohull \\
\hline Heave Amplitude & 0.540 & 0.540 & 0.539 & 0.539 & 0.698 \\
\hline Heave Velocity & 0.575 & 0.575 & 0.575 & 0.575 & 0.777 \\
\hline Heave Acceleration & 0.630 & 0.629 & 0.629 & 0.629 & 0.886 \\
\hline Pitch Amplitude & 2.080 & 2.080 & 2.080 & 2.080 & 1.080 \\
\hline Pitch Velocity & 0.040 & 0.040 & 0.040 & 0.040 & 0.022 \\
\hline Pitch Acceleration & 0.044 & 0.044 & 0.044 & 0.044 & 0.027 \\
\hline Roll Amplitude & 0.870 & 0.970 & 1.160 & 1.220 & 1.080 \\
\hline Roll Velocity & 0.015 & 0.017 & 0.022 & 0.023 & 0.023 \\
\hline Roll Acceleration & 0.016 & 0.019 & 0.024 & 0.026 & 0.037 \\
\hline
\end{tabular}

Table 8 Comparison of the motion root mean square in Head Sea

Tablica 8. Usporedba korijena srednjeg kvadrata kretanja na valovima s pramca

\begin{tabular}{|l|c|c|c|c|}
\hline \multicolumn{1}{|c|}{ Motion Type } & s/L 0.17 & s/L 0.20 & s/L 0.30 & s/L 0.40 \\
\hline Heave Amplitude & 0.296 & 0.296 & 0.296 & 0.296 \\
\hline Heave Velocity & 0.316 & 0.316 & 0.316 & 0.316 \\
\hline Heave Acceleration & 0.345 & 0.345 & 0.345 & 0.345 \\
\hline Pitch Amplitude & 1.440 & 1.440 & 1.440 & 1.440 \\
\hline Pitch Velocity & 0.028 & 0.028 & 0.028 & 0.028 \\
\hline Pitch Acceleration & 0.032 & 0.032 & 0.032 & 0.028 \\
\hline
\end{tabular}


Regarding the motion root means square (RMS) results, in the beam sea, most of the motions RMS have a good agreement with the motion spectra density characteristics, Fig. 14. It can be seen that the heave and pitch motions of all catamarans have similar amplitude, velocity, and acceleration, Table 6. Otherwise, all catamarans have shown a slightly different roll motion performance because of the demihulls variation. Comparing with the monohull, the heave and the roll motion RMS have shown a similar tendency with the motion spectra density. The monohull has shown a better heave motion performance, while the catamarans present a better roll motion. Nevertheless, the monohull pitch motion RMS has shown a better performance than the catamarans. This RMS has demonstrated a different tendency with the motion spectra density. This condition might have occurred because the line chart shape of both motion spectra density charts is slightly different. The pitch motion spectra chart of monohull have a steep line curve while the catamarans are gentle one. Although the monohull showed the largest maximum point, however, the catamarans have a greater area under the motion energy spectrum, Fig. 14b. These calculation results are appropriate for the characteristics of slender bodies (catamarans) that generally have a smaller pitch damping motion than the monohull.

In the Bow Quartering and Head Sea, the RMS of heave and pitch motion of the catamarans have a similar value as figured in the motion spectra chart, Figs. 15 and 16. The variation of the RMS of the catamarans roll motion can also be recognized only on the Beam Sea, and it has the same tendency with the motion spectra chart, Fig. $15 \mathrm{c}$. It is also can be seen that the RMS of monohull roll motion is larger than the catamarans with $s / L=0.17$ and $s / L=0.20$. It is indicated that the greater demi hull spacing might not improve the roll motion in the Bow Quartering Sea.

\section{CONCLUSION / Zaključak}

The development of the catamaran hull forms for fish processing vessels to support domestic fishing activities was made. The principal dimension was determined with a comparison method using the linear regression equation model. The variation of the demi-hull spacing ratio and the parent model modification was conducted during the exploration of the hull shape. The numerical assessment of the developed catamaran hulls presented the results that can be concluded as recommendations on their practical applicability, significantly to improve the fishing operations in Indonesia.

The resistance evaluation result shows that the catamarans have an optimum total resistance on the service speed over 23 knots. Although the catamarans hull can reduce the wavemaking resistance effect, the wave interference resistance has contributed to the escalation of the total resistance, especially on the service speed below 17 knots. Nevertheless, the large demi hull spacing ratio $(\mathrm{s} / \mathrm{L}=0.4)$ was able to reduce the resistance effect. It is indicated that the catamarans hull is appropriately applied to the fast fishing boat that saves sailing time during the fishing operation.

The catamarans hull presented intact stability performance with the large righting lever arm (GZ) on the small heeling angle. The large demi-hull spacing ratio $(\mathrm{s} / \mathrm{L}=0.4)$ generated $\mathrm{a}$ broader and larger deck boat which increased the metacentre height. Although the large righting arm has a tendency to cause the stiff roll motion response, however the twin slender hull bodies able to reduce the effect of wave excitation load on the motion response. Therefore, it can be concluded that the catamarans have provided better intact stability with an acceptable roll motion response.

The sea-keeping analysis shows that the catamarans hull able to reduce the effect of the wave exciting load on the roll motion response at the Beam Sea. The significant demi hull distance can reduce the RAO roll motion in a $90^{\circ}$ wave heading angle. Otherwise, the slender twin hull generates a more significant RAO pitch motion than the monohull in Bow Quartering and Head Sea. The slender body generally has a small waterplane area that generates small pitch motion damping. Therefore, it can be concluded that the catamarans can be appropriately applied for offshore loading/unloading activities (as mother vessel) or the seaways environment that the Beam Sea frequently occurs, such as the Indian Sea environment.

Although the larger demi hull spacing has presented an improvement of resistance, intact stability, and roll motion behaviour, however, the significant increment of demi hull separation also may lead to the increase of lightweight and the production cost that might be greater than the improvement benefit.

\section{ACKNOWLEDGEMENT / Zahvala}

This work was funded by the Directorate of Research and Community Service, Ministry of Research, Technology and Higher Education Indonesia, through the Fundamental Research Scheme-2020 (Penelitian Dasar-2020), Diponegoro University, and Contract Number: 257-26/UN7.6.1/PP/2020.

\section{REFERENCES / Literatura}

[1] Directorate General of Capture Fisheries. (2019) Indonesia Capture Fisheries Statistics. Ministry of Marine Affairs and Fishery Indonesia.

[2] Petursdottir, G., Hannibalsson, O., Turner, J.M.M. (2001) Safety at Sea as an Integral Part of Fisheries Management. FAO Fisheries Circular No. 966. Food and Agriculture Organization of the United Nations (FAO).

[3] BLS. (2014) National Census of Fatal Occupational Injuries in 2013 (Preliminary Results). Bureau of Labor Statistics. US Department of Labor.

[4] MESS. (2014) Estadística de Accidentes de Trabajo. Ministerio de Empleo y Seguridad Social. Subdireccion General de Estadísticas. Gobierno de Espana.

[5] Roberts, S.E. (2010) Britain's most hazardous occupation: commercial fishing. Accid. Analysis Prev., vol. 42, no. 1, pp. 44-49. https://doi.org/10.1016/j. aap.2009.06.031

[6] Krata, P. (2008). Total losses of fishing vessels due to the insufficient stability. Int J. Mar. Navigation Saf. Sea Transp., vol. 2, no. 3, pp.311-315.

[7] Míguez Gonzalez, M., Caamano Sobrino, P., Tedín Alvarez, R., Díaz Casas, V., Martínez Lopez, A., Lopez Pena, F. (2012) Fishing vessel stability assessment system. Ocean. Eng. Vol. 41, pp. 67-78. https://doi.org/10.1016/j. oceaneng.2011.12.021

[8] Wolfson Unit. (2004) MCA Research Project 530. Simplified Presentation of Fishing Vessels Stability Information. Phase 1. Final Report. Wolfson Unit. The University of Southampton.

[9] I K. A. P. Utama. (2006) Experimental Analysis of Catamaran Resistance on the Variation of Demihull Spacing. Jurnal Penelitian Engineering, Vol. 12, No. 1.

[10] M. Insel and A. F. Molland. (1992) An investigation into the resistance components of high-speed displacement catamarans. Transactions of the Royal Institution of Naval Architects, RINA, Vol. 134.

[11] H. Turner and A. Taplin. (1968) The resistance of large-powered catamaran. Transactions of the Society of Naval Architects and Marine Engineers, SNAME, Vol. 76

[12] Zakki, A.F., Windyandari, A., Chrismianto, D., Habib, I. (2019) Development of Monohull Fish Processing Vessel Hullform to Support Domestic Fishing Activities in Indonesia. International Journal of Innovative Technology and Exploring Engineering (IJITEE), vol. 9, no. 2, pp.441-447. https://doi.org/10.35940/ijitee. A4181.119119

[13] Molland, A.F., Wellicome, J., Couser, P. (1996) Resistance experiments on a systematic series of high-speed catamaran forms: variation of lengthdisplacement ratio and breadth-draught ratio. Transactions of the Royal Institution of Naval Architects 138, pp.59-71. 
[14] Bruzzone, D., Ferrando, M. (1995) Numerical evaluation of the steady free surface flow for catamaran hull forms. In: Proceedings of the III Symposium on High-Speed Marine Vehicles. Naples, pp. 187-198.

[15] Muller-Graf, B., Radojcic, D., Simic, A. (2002) Resistance and propulsion characteristics of the VWS hard chine catamaran hull series '89. SNAME Transactions, 110. https://doi.org/10.5957/mt1.2003.40.4.303

[16] Welnicki, W. (1994) The Influence of Hull Shape on Hydrodynamic Characteristics of Fast Catamaran. In: Proceedings of the 5th International Marine Design Conference.

[17] Welnicki, W. (1997) Some Hydromechanic Aspect of Fast Wave Piercing Catamarans Resistance, Stability and Manoeuvrability. In: Proceedings of the 5th International Marine Design Conference.

[18] Doctors, L. (2003) The influence of viscosity on the wave-making of a model catamaran. In: Proceedings of the 8th International Workshop on Water Waves and Floating Bodies, pp. 121

[19] Armstrong, T. (2003) The effect of demi-hull separation on the frictional resistance of catamarans. In: Proceedings of the 7th International Conference on Fast and Sea Transportation.

[20] Molland, A., Wilson, P., Taunton, D., Chandraprabha, S., Ghani, P. (2004) Resistance and wash measurements on a series of high-speed displacement monohull and catamaran forms in shallow water. International Journal of Maritime Engineering 146, pp. 19-38. https://doi.org/10.3940/rina.ijme.2004.a2.3604

[21] Millward, A. (1992) The effect of hull separation and restricted water depth on catamaran resistance. Transactions of Royal Institution of Naval Architects 134, pp. 341-349.

[22] Souto-Iglesias, A., Zamora-Rodríguez, R., Fernández-Gutiérrez, D., Pérez Rojas, L. (2007) Analysis of the wave system of a catamaran for CFD validation Experiments in Fluids, vol. 42, pp.321-333. https://doi.org/10.1007/s00348006-0244-4

[23] Souto-Iglesias, A., Fernandez-Gutierrez, D., Perez-Rojas, L. (2012) Experimental assessment of interference resistance for a Series 60 catamaran in free and fixed trim-sinkage conditions. Ocean Engineering, vol. 53, pp.38-47. https://doi. org/10.1016/j.oceaneng.2012.06.008

[24] Broglia, R., Aloisio, G., Falchi, M., Grizzi, S., Zaghi, S., Felli, M., Miozzi, M., Pereira, F., Di Felice, F., Stern, F. (2012) Measurements of the velocity field around the DELFT 372 catamaran in steady drift. In: Proceedings of the 29th Symposium on Naval Hydrodynamics Gothenburg. Sweden.

[25] Kogan, E.M. (1971) To the calculation of main part of disturbing forces for oscillating catamaran in liquid of finite depth. In: Proceedings of Nikolaev Shipbuilding Institute of adm. S.O. Makarov. (in Russian).

[26] Lee, C.M., Jones, H.D., Curphey, R.M. (1973) Prediction of motion and hydrodynamics loads of catamarans. Marine Technology, Vol. 10, No. 4, pp. 392-405.

[27] Faltinsen, O.M., Helmers, J.B., Minsaas, K.J., Zhao, R. (1991) Speed loss and operability of catamarans and SES in a seaway In: Holden, K.O., Faltinsen, O.M., Moan., T. (Eds.), Proceedings of the FAST'91, vol. 2. Tapir Publishers, Trondheim, pp. $709-725$

[28] Castiglione, T., Stern, F., Bova, S., Kandasamy, M. (2011) Numerical investigation of the sea-keeping behavior of a catamaran advancing in regular head waves. Ocean Engineering vol. 38, no 16, 1806-1822. https://doi.org/10.1016/j. oceaneng.2011.09.003

[29] Bouscasse, B., Broglia, R. and Stern, F. (2013) Experimental investigation of a fast catamaran in head waves. Ocean Engineering, vol. 72, pp.318-330. https:// doi.org/10.1016/j.oceaneng.2013.07.012

[30] Piscopo, V. and Scamardella, A. (2015) The overall motion sickness incidence applied to catamarans. Int. J. Nav. Archit. Ocean Eng., vol. 7, pp. 655-669. https://doi.org/10.1515/ijnaoe-2015-0046
[31] Pandey, J., Hasegawa, K. (2016) Study on Turning Maneuver of Catamaran Surface Vessel with a Combined Experimental and Simulation Method. IFACPapers online 49-23, pp. 446-451. https://doi.org/10.1016/j.ifacol.2016.10.446

[32] Davis, M.R., French, B.J., Thomas, G.A. (2017) Wave slam on wave-piercing catamarans in random head seas. Ocean Engineering, vol.135, pp. 84-97. https://doi.org/10.1016/j.oceaneng.2017.03.007

[33] Navsea (2020) Navy Accepts Delivery of USNS Newport (Press release). US Navy. 3 September 2020. Retrieved 3 September 2020.

[34] Jeong, U.C., Kim, H.S., Choi, J.H. (2015) Study of Hull Form Development of 5-Ton-Class Catamaran-Type Coastal Fishing Boat for Welfare Accommodation of Fishing Crew. Journal of Ocean Engineering and Technology, Vol. 29, No. 6 , pp. 405-410. https://doi.org/10.5574/KSOE.2015.29.6.405

[35] Setyawan, D., Utama, I.K.A.P., Murdijanto, Sugiarso, A. Jamaluddin (2010) Development of Catamaran Fishing Vessel. IPTEK The Journal for Technology and Science, Vol. 21, No. 4, pp. 167-173. https://doi.org/10.12962/j20882033. v21i4.90

[36] Carchen, A., Atlar, M., Turkmen, S., Pazouki, K. Murphy, A.J. (2019) Ship performance monitoring dedicated to biofouling analysis: Development on a small size research catamaran. Applied Ocean Research, Vol. 89, pp. 224-236. https://doi.org/10.1016/j.apor.2019.05.005

[37] Zakki, A.F., Windyandari, A., Suharto, Ramadhan, A. (2019) Comparative Study on Catamaran and Monohull for the Hull Form Design of Livestock Carrier. Journal of Engineering Science and Technology Vol. 14, No. 4, pp. 2074-2089.

[38] Jamaluddin, A. (2012). Experimental and Numerical Investigation into the Viscous and Wave Resistance Interferences of Catamarans (in Indonesian), Ph.D. Thesis, Faculty of Marine Technology, Institute Technology of Sepuluh Nopember, Indonesia.

[39] A Jamaluddin, I K A P Utama, B Widodo, and A F Molland, 2013. Experimental and Numerical Study of the Resistance Component Interactions of Catamarans. Journal of Engineering for the Maritime Environment, Procs. the Institution of Mechanical Engineers Part M, Vol. 227, Issue 1, February, pp. 51-60. https:// doi.org/10.1177/1475090212451694

[40] FAO (2005). Voluntary Guidelines for the Design, Construction, and Equipment of Small Fishing Vessels. IMO Publishing, London.

[41] IMO (1993). Code on Intact Stability for All Types of Ship Covered by IMO Instruments. International Maritime Organization.

[42] HSC Code (2000). International Code of Safety for High-Speed Craft. The Maritime and Coastguard Agency.

[43] Kurniawan, R., Khotimah, M.K. (2015) Ocean Wave Characteristics in Indonesian Waters for Sea Transportation Safety and Planning. IPTEK The Journal for Technology and Science, Vol. 26, No. 1, pp. 19-27. https://doi.org/10.12962/ j20882033.v26i1.767

[44] Setiyawan, Salim, H., Lukman, R.T., Hadi, S., Hadihardaja, I.K. (2013) Spectral Representation in Pacitan and Meulaboh Coast. International Journal of Civil \& Environmental Engineering, vol. 13, no. 1, pp. 29-34.

[45] Iqbal, M., Rindo, G. (2016) The Influence of Anti-Slamming Bulbous Bow on the Slamming Motion of 200 DWT Pioneer Vessel. Kapal, vol. 13, no. 1, pp. 45-54. https://doi.org/10.12777/kpl.13.1.45-54

[46] Adrianto, D., Djatmiko, E.B., Suntoyo (2019) The improvement of the ultrasonic sensor-based device for direct ocean wave measurement program at Western Java Sea - Indonesia. IOP Conf. Series: Earth and Environmental Science, vol. 389, pp. 1-11. https://doi.org/10.1088/1755-1315/389/1/012022

[47] Adrianto, D., Djatmiko, E.B., Suntoyo (2020). The 6-Hz wave measurements in the Western Java Sea and its preliminary characteristics analysis. AES Bioflux vol. 12 , no. 1 , pp. 66-82. 